\title{
Efektivitas Penggunaan Internet Sebagai Media Komunikasi Dalam Meningkatkan Tugas Akhir Mahasiswa Akademi Komunikasi
}

\author{
Riastri Novianita $^{\# 1}$, Rosiana Andhikasari ${ }^{\# 2}$, Cindya Yunita Pratiwi ${ }^{\# 3}$ \\ ${ }^{\#}$ Fakultas Komunikasi dan Bahasa, Universitas Bina Sarana Informatika \\ Jl. Kramat Raya No.98, RT.2/RW.9, Kwitang, Kec. Senen, Kota Jakarta Pusat \\ $\frac{1 \text { riastri.rsvebsi.ac.id }}{2 \text { rosiana.rorebsi.ac.id }}$ \\ ${ }^{3}$ cindya.cyp@bsi.ac.id
}

\begin{abstract}
This study emphasizes the use of the internet as a communication medium for students of the UBSI Communication Academy in improving their final assignments, and also sees its effectiveness in supervisors and students. Internet activities used in this study are www, email, and news groups, as well as to find out what media are used by lecturers and students in conducting final assignment guidance activities. This research is a descriptive study with a qualitative approach. The research method chosen in this research is a case study, because the researcher feels this is appropriate in describing in depth the phenomenon under study. From all the lecturers and students, it can be concluded that UBSI lecturers and students are familiar with the use of the internet in everyday life. Students are able to receive input and teaching from lecturers during guidance using internet applications, so that in the future the process of final assignment guidance activities which are usually done manually face-to-face can be transferred to digital such as using zoom, WhatsApp, and others.
\end{abstract}

Keyword: internet, commucation media, college student.

Abstrak - Penelitian ini menekankan pada penggunaan intenet sebagai media komunikasi mahasiswa Akademi Komunikasi UBSI dalam meningkatkan tugas akhir, dan juga melihat efektivitasnya pada dosen pembimbing dan mahasiswa. Aktivitas internet yang digunakan dalam penelitian ini adalah www, email, dan news group, juga untuk mengetahui media apa saja yang digunakan oleh dosen dan mahasiswa dalam melakukan kegiatan bimbingan tugas akhir. Penelitian ini merupakan penelitian deskriptif dengan pendekatan kualitatif. Metode penelitian yang dipilih dalam penelitian ini yaitu studi kasus, karena peneliti merasa hal ini tepat dalam menggambarkan secara mendalam tekait fenomena yang diteliti. Dari semua narasumber dosen pembimbing dan mahasiswa tersebut dapat diambil kesimpulan bahwa dosen dan mahasiswa UBSI sudah terbiasa dengan penggunaan internet dalam kehidupan sehari-hari. mahasiswa mampu menerima masukan dan pengajaran dosen selama bimbingan menggunakan aplikasi internet, sehingga untuk kedepannya proses kegiatan bimbingan tugas akhir yang biasanya dilakukan secara manual dengan tatap muka langsung dapat dialihkan ke digital seperti penggunaan zoom, whatsapp, dan lain-lain.

Kata kunci: internet, media komunikasi, mahasiswa.

\section{PENDAHULUAN}

Penggunaan internet di masyarakat semakin luas dan berasal dari semua kalangan jika dulu internet lebih banyak dimanfaatkan untuk kepentingan hiburan, saat ini internet juga banyak digunakan untuk mengakses informasi untuk keperluan pendidilkan. Para dosen dan mahasiswa saat ini banyak yang menggunakan internet sebagai media komunikasi, salah satunya adalah untuk kegiatan pengerjaan tugas akhir.

Dalam proses pembalajaran, seorang guru atau pengajar memiliki peranaan penting demi tercapainya kegiatan pembelajaran di kampus. Dosen juga menjadi ujung tombak terciptanya kegiatan proses pembelajaran. Dengan adanya media tersebut setiap mahasiswa mampu memanfaatkan internet sesuai dengan kebutuhan pendidikan. Di samping itu pemanfataan internet sebagai media pembelajaran sangat mempermudah mahasiswa dalam mengakses sebuah informasi pengetahuan mengirim tugas-tugas kampus lewat e-mail, dan sebagainya. Selama mahasiswa, dosen, gurtu atau pengajar juga dapat mempermudah dalam menyampaikan pembelajaran. Pemanfaatan media internet sangat penting bagi terlaksananya pembelajaran yang baik.

Literatur internet meliputi kemampuan untuk menemukan mengatur, memahami, menganalisis, mengevaluasi dan 
menghasilkan informasi yang diperoleh melalui penggunaan internet. Maka demikian para pembimbing dan mahasiswa yang menggunakan internet harus sangat jeli dalam memilah informasi yang ada pada internet.

Pada hibah Penelitian Dosen Pemula ini peneliti ingin mencari tahu apakah para pembimbing dan mahasiswa yang sedang mengerjakan tugas akhir memanfaatkan fasilitas internet dengan baik dan apakah penggunaan internet efektif dalam proses kegiatan bimbingan dikarenakan tidak semua dosen pembimbing dan mahasiswa memahami akan penggunaan internet. Berdasarkan latar belakang masalah diatas maka rumusan masalah penelitian ini adalah apakah ada kesenjangan digital tehadap literasi internet dosen pembimbing dan mahasiswa Universitas Bina Sarana Informatika yang sedang mengerjakan tugas akhir.

Untuk itu tujuan peneltian ini adalah mengetahui kesenjangan digital tehadap literasi internet dosen pembimbing dan mahasiswa Universitas Bina Sarana Informatika yang sedang mengerjakan tugas akhir. Manfaat dalam penelitian ini adalah secara teoritis, diharapkan penelitian ini dapat mengembangkan wawasan dan pengetahuan di kalangan mahasiswa dan dosen di bidang komunikasi khususnya literasi penggunaan internet, dan kegunaan secara praktis penelitian ini diharapkan dapat bermanfaat sebagai masukan ataupun bahan yang dapat digunakan oleh mahasiswa ataupun dosen untuk mengetahui adanya kesenjangan digital mengenai literasi internet.

\section{Tinjauan Pustaka}

Universitas Bina Sarana Informatika merupakan perguruan tinggi swasta yang berada di Jakarta, Indonesia. Universitas Bina Sarana Informatika didirikan oleh Lembaga Pendidikan Komputer Bina Sarana Informatika (LPK BSI) pada tanggal 3 Maret 1988 yang berlokasi di Depok. Lembaga pendidikan ini memiliki sebuah tujuan untuk mendidik tenaga-tenaga terampil atau profesional dalam bidang komputer, dan juga untuk memenuhi kebutuhan sumber daya manusia dalam melakukan pembangunan nasional.

Adanya kepercayaan yang begitu besar dari masyarakat untuk LPK BSI, sehingga pada bulan Oktober tahun 1989, kantor pusat Yayasan Bina Sarana Informatika melakukan pemindahan kegiatannya ke Jakarta sekaligus juga untuk meresmikan cabang kedua LPK BSI. Saat BSI berpindah kantor pusat di Jakarta, masyarakat semakin memberikan kepercayaannya untuk BSI, sehingga untuk mendapatkan peserta didik atau mahasiswa, maka BSI secara berturut-turut dan dengan persiapan yang sangat matang maka BSI mampu mendirikan beberapa cabang dalam waktu singkat. Dan pada tahun 1990 Yayasan Bina Sarana Informatika mulai mendirikan program pendidikan siap kerja yang disebut dengan Politeknik Bina Sarana Informatika, jurusan yang pertama kali dibuat adalah Akuntansi Komputer dan angkatan pertama yang ada pada tahun ajaran 1990/1991.

Saat ini Universitas Bina Sarana Informatika (UBSI memiliki visi yaitu menjadi universitas unggul pada bidang ekonomi kreatif pada tahun 2033. Sedangkan misi dari Universitas Bina Sarana Informatika (UBSI) juga memiliki beberapa misi, yaitu:

1. Melakukan program pendidikan akademik dan juga vokasi guna mendukung ekonomi kreatif

2. Melakukan penelitian yang berkualitas

3. Melakukan kegiatan pengabdian masyarakat dalam rangka guna meningkatkan kualitas sumber daya manusia dalam hal ini dosen dan mahasiswa.

4. Mengelola universitas ini secara mandiri menggunakan tata kelola yang baik dengan melakukan pengembangan kelembagaan yang berorientasi pada mutu.

Universitas Bina Sarana Informatika (UBSI) juga memiliki beberapa tujuan, yaitu:

1. Mampu menghasilkan lulusan UBSI yang memiliki beberapa kemampuan yaitu dalam bidang mengembangkan, mengimplementasikan dan menyebarkan teknologi pada bidang ekonomi kreatif yang disesuaikan dengan kebutuhan masyarakat, industri dan juga dunia usaha

2. Mampu menghasilkan lulusan yang memiliki kompetensi, kreatif, inovatif, kompetitif dan juga memiliki akhlak mulia

3. Mampu menghasilkan penelitian dan karya Ilmiah yang telah diakui pada tingkat nasional maupun internasional

4. Mewujudkan kegiatan pengabdian dan pemberdayaan masyarakat dimana mampu mendorong pengembangan potensi sumber daya manusia yang ditujukan mewujudkan adanya kesejahteraan masyarakat

5. Mampu mewujudkan suasana akademik yang dapat mendukung bakat, minat, dan kreativitas dimana dapat menunjang pengembangan ekonomi kreatif.

6. Mampu menciptakan tata kelola universitas yang baik.

Salah satu fakultas yang ada di UBSI adalah Fakultas Komunikasi dan Bahasa, yang memiliki visi menjadikan Fakultas Komunikasi dan Bahasa yang unggul terutama dalam hal pengembangan keilmuan teknologi dan informasi dalam rangka mendukung ekonomi kreatif tahun 2033. Fakultas Komunikasi dan Bahasa juga memiliki visi, yaitu:

1. Mampu melaksanakan pendidikan pada bidang komunikasi dan bahasa yang memiliki kualitas baik

2. Mampu melaksanakan penelitian pada bidang komunikasi dan bahasa yang memiliki kualitas baik

3. Mampu melaksanakan pengabdian masyarakat pada bidang komunikasi dan bahasa agar mampu meningkatkan kualitas sumber daya manusia

4. Mampu mengatur fakultas secara mandiri namun tetap dengan tata kelola yang baik.

\section{A. Komunikasi Antar Pribadi}

Komunikasi interpersonal atau dapat disebut dengan komunikasi antar pribadi merupakan komunikasi yang terjadi pada dua orang atau lebih, dapat terjadi secara terorganisir atau kelompok. Dalam komunikasi interpersonal terpadat pesan yang disampaikan dengan adanya timbal balik. Menurut Barnlund, komunikasi interpersonal merupakan 
pertemuan antara dua, tiga orang atau lebih yang mana terjadi secara spontan dan tidak terstruktur [1].

\section{B. Internet}

Sosiawan [2] menyatakan bahwa secara rinci komunikasi bermedia internet dalam proses penggunaannya dapat diuraikan menjadi tiga, yaitu:

1. Aktivitas dan proses komunikasi bermedia internet meliputi:

a. Menciptakan pengertian dengan menulis "surat" melalui $e$-mail, menuliskan kata-kata pada waktu yang sama dalam komunitas chatting, serta menciptakan web sites melalui penciptaan file multimedia.

b. Menyebarkan pengertian melalui komunikasi point to point (e-mail), dan komunikasi point to multi point (IRc, web site).

c. Merasakan arti dalam teks dan multimedia pada web sites, e-mail dan IRC.

d. Berpartisipasi dalam forum untuk berkomunikasi yang merupakan awal penjelajahan karakteristik komunitas seperti tujuan bersama, norma-norma dan tradisi.

e. Level dan konteks komunikasi bermedia internet.

Meskipun dalam aktivitas dan proses komunikasi bermedia internet adalah pertukaran data melalui komputer namun tetap melibatkan manusia sebagai pemberi konteks atau situasi pada aktivitas dan process komunikasi tersebut, yang meliputi konteks individual, group, organisasi, massa dan sosial. Pada level individual, pengguna menggunakan internet tools untuk mencari dan menerima informasi dan berkomunikasi dengan pengguna lain. Electronic mail adalah fasilitas yang paling banyak digunakan pada level ini. Pada tingkatan di atasnya yaitu level group communications, electronic mail masih tetap digunakan dalam bentuk listserver atau mailng list serta penggunaan IRc. Tingkatan komunikasi massa adalah fasilitas broadcast on line yaitu Web sites identik dengan komunikasi di level ini.

2. Prespektif lintas budaya

Karena karakteristik yang mampu melintas jarak dan batas benua, maka dimungkinkan komunikasi bermedia internet akan memiliki fenomena terjadinya pertukaran antar budaya. Dalam penggunaanya user internet akan menjadi semakin bertambah partisipasinya dalam pertukaran budaya dan penghubung pertukaran budaya itu sendiri.

Surat elektronik atau electronic mail (e-mail) adalah fasilitas surat menyurat berbasiskan media web/internet. Berbeda dengan surat secara fisik, pengiriman surat dilakukan secara otomatis dengan software yang sudah disediakan. Sebagai pengganti alamat pengiriman, para pengguna e-mail harus memiliki akun (account) yang menunjukkan diri pengguna. Dewasa ini, banyak penyedia jasa e-mail (provider) di internet, seperti yahoo, google, hotmail, dsb.

Para penyedia ini memiliki space/ruang di jaringan internet yang disebut dengan domain. Domain diibaratkan sebagai "rumah" bagi para pengguna $e$-mail. Bila pengguna membuat sebuah akun, maka akun tersebut akan memiliki alamat domain. Contohnya, enni@yahoo.com, “enni” adalah alamat khusus yang menunjukkan (alamat) pengguna, adapun "yahoo" menunjukkan domain dimana user atau pengguna yang menggunakan nama budi itu membuat akun.

Komunikasi yang terjadi melalui $e$-mail cenderung tidak intim. Hal ini dikarenakan proses komunikasi yang terjadi cenderung tidak pasti (karena ada jeda) responnya. Selain itu, bahasa atau isi dari e-mail sendiri juga cenderung bersifat formal karena berbentuk surat.

\section{METODE PENELITIAN}

Penelitian ini merupakan penelitian deskriptif dengan pendekatan kualitatif. Metode kualitatif merupakan metode penelitian yang digunakan untuk meneliti pada kondisi objek yang alami yang tidak berusaha untuk mencari pengaruh variabel tertentu terhadap variabel yang lain di mana peneliti adalah sebagai instrumen kunci.

Penelitian kualitatif adalah penelitian yang bermaksud untuk memahami fenomena tentang apa yang dialami oleh subjek penelitian misalnya perilaku, cara deskripsi dalam bentuk kata-kata dan bahasa, pada suatu konteks khusus yang alamiah dan dengan memanfaatkan berbagai metode alamiah [3].

Penelitian kualitatif tidak menggunakan istilah populasi, tetapi menggunakan "social situation" atau situasi sosial yang terdiri atas tiga elemen yaitu : tempat (place), pelaku (actor), dan aktivitas (activity) yang berinteraksi secara sinergis [4].

Penelitian ini dilaksanakan di Kampus Universitas Bina Sarana Informatika yang berlokasi di Jalan Kayu Jati V No.2 RT.9/RW.5 Rawamangun, Pulo Gadung Jakarta. Adapun waktu pelaksanaan penelitian pada bulan Januari-Desember 2020.

Metode penelitian yang dipilih dalam penelitian ini yaitu studi kasus, karena peneliti merasa hal ini tepat dalam menggambarkan secara mendalam tekait fenomena yang diteliti. Bungin [5] menyatakan bahwa studi kasus adalah suatu inquiry empiris yang mendalami suatu fenomena dan konteks tak tampak secara tegas.

Adapun keistimewaan studi kasus menurut Lincoln dan Guba, sebagaimana dikutip Mulyana[1], keistimewaan Studi Kasus meliputi hal-hal sebagai berikut:

1. Studi Kasus merupakan sarana utama bagi penelitian emik, yakni menyajikan pandangan subjek yang diteliti.

2. Studi Kasus menyajikan uraian menyeluruh yang mirip dengan apa yang dialami pembaca dalam kehidupan sehari-hari (everyday real-life).

3. Studi Kasus merupakan sarana efektif untuk menunjukkan hubungan antara peneliti dengan subjek atau informan. 
4. Studi Kasus memungkinkan pembaca untuk menemukan konsistensi internal yang tidak hanya merupakan konsistensi gaya dan konsistensi faktual tetapi juga keterpercayaan (trustworthiness).

5. Studi Kasus memberikan "uraian tebal" yang diperlukan bagi penilaian atas transferabilitas.

6. Studi Kasus terbuka bagi penilaian atas konteks yang turut berperan bagi pemaknaan atas fenomena dalam konteks tersebut.

Dalam penelitian ini menggunakan teknik pemilihan informan peneliti yang didasarkan pada pertimbangan tertentu yang relevan terhadap penelitian yang sesuai dengan tujuan yang diharapkan dari penelitian.Dalam hal ini peneliti memilih subjek penelitian ini yaitu mahasiswa dan dosen pembimbing.

Pengumpulan data pada penelitian ini menggunakan beberapa teknik untuk memperoleh data yang lengkap diantaranya sebagai berikut:

1. Observasi

2. Wawancara

3. Dokumentasi

Dalam penelitian kualitatif, analisis data lebih difokuskan selama dilapangan bersamaan dengan pengumpulan data. Peneliti menggunakan model analisis Miles and Huberman, komponen dalam analisis data tersebut adalah

\section{Data Reduction (Reduksi Data)}

Mereduksi data berarti merangkum, memilih hal-hal pokok, memfokuskan hal-hal yang penting, dicari tema dan polanya dan membuang yang tidak perlu. Data display (penyajian data). Dalam penelitian kualitatif, penyajian data bisa dilakukan dalam bentuk uraian singkat, bagan, hubungan antar kategori, followchart dan sebagainya.

\section{Conclusion drawing/verification}

Menurut Miles and Huberman adalah penarikan kesimpulan dan verifikasi. Kesimpulan awal yang dikemukakan masih bersifat sementara, dan akan berubah bila tidak ditemukann bukti-bukti yang kuat mendukung pada tahap pengumpulan data berikutnya.

\section{HASIL DAN PEMBAHASAN}

Komunikasi antar pribadi sangat penting dalam kegiatan bimbingan Tugas Akhir bagi mahasiswa tingkat akhir Akademi Komunikasi Fakultas Komunikasi dan Bahasa Universitas Bina Sarana Informatika. Kegiatan bimbingan membutuhkan adanya pesan yang disampaikan dan diperlukan adanya timbal balik dari dosen pembimbing dan mahasiswa bimbingan agar proses komunikasi dapat berjalan dengan lancar. Di Akademi Komunikasi terdapat tiga program studi yaitu penyiaran, hubungan masyarakat, dan periklanan. Kampus UBSI tidak terpusat di satu lokasi saja namun tersebar di beberapa daerah sehingga agak sedikit meyulitkan mahasiswa melakukan bimbingan tugas akhir. Selain itu dengan situasi Jabodetabek yang sering terjadi kemacetan maka semakin menyulitkan mahasiswa melakukan bimbingan tatap muka secara langsung dalam waktu singkat, maka dari itu UBSI memberikan fasilitas kepada mahasiswa dan dosen untuk dapat melakukan bimbingan secara online.

Internet menjadi sangat penting dalam hal ini karena menjadi salah satu sumber yang dapat digunakan mahasiswa dalam mencari literasi untuk mengerjakan tugas akhir dalam hal ini dapat berupa jurnal, ebook, website yang memiliki keterkaitan dengan tugas akhir yang dikerjakan, elearning yang sudah disediakan kampus untuk melihat repositori tugas akhir mahasiswa yang sudah lulus. Selain itu mahasiswa dapat menggunakan berbagai aplikasi untuk melakukan komunikasi dengan dosen pembimbing seperti whatsapp, zoom, email, dan lain sebagainya.

Adanya kemudahan dalam melakukan komunikasi pada saat ini telah dimanfaatkan oleh dosen dan mahasiswa UBSI dalam melakukan bimbingan khususnya pada mahasiswa tingkat akhir akademi komunikasi yang sedang mengerjakan tugas akhir. Pada penelitian ini terdapat total 12 narasumber yang terdiri dari 6 dosen pembimbing dan 6 mahasiswa tingkat akhir akademi komunikasi UBSI yang sedang melakukan kegiatan bimbingan tugas akhir.

Berdasarkan hasil wawancara pada dosen pertama menunjukkan hasil bahwa dosen tersebut sudah mengetahui dengan jelas apakah itu internet dan aplikasi internet apa saja yang sering digunakan seperti www, email, dan news group. Pengetahuan tentang www, email, dan news group juga sudah sangat baik, dari ketiga unit analisis tersebut yang banyak digunakan oleh dosen pertama adalah email. Dalam melakukan bimbingan, dosen tersebut memanfaatkan media whatsapp, zoom, dan google meet. Penggunaan berbagai aplikasi internet yang tersedia saat ini membantu dosen dan pembimbing dalam melakukan kegiatan bimbingan tugas akhir dan mahasiswa dapat dengan mudah mengerti apa yang disampaikan oleh dosen pembimbing walau tidak dengan tatap muka secara langsung.

Setelah bimbingan perdana usai, mahasiswa secara personal dapat menghubungi dosen pembimbing melalui nomor gawai untuk konsultasi sesuai jadwal yang disediakan melalui media virtual. Di akhir periode waktu bimbingan dosen pembimbing mengadakan bimbingan simulasi sidang tugas akhir kepada mahasiswa atau mahasiswi yang dinilai layak untuk didaftarkan pada sidang tugas akhir. Jika dalam keadaan normal, bimbingan simulasi sidang tugas akhir dilakukan di kelas secara tatap muka.

Dosen pembimbing berkoordinasi dengan administrasi kampus untuk memesan kelas kosong dengan jadwal tertentu, atau video conference melalui aplikasi zoom atau google meet. Sejauh ini mahasiswa paham dan mayoritas 80 persen dapat terus berlanjut pada bimbingan bab selanjutnya dengan waktu relatif cepat. Berbeda hal, jika mahasiswa itu sendiri yang memang dari awal tidak berniat menghubungi dosen pembimbing dan meminta konsultasi dengan dosen pembimbing. Ketika mahasiswa mampu memahami dan mengerti apa yang dosen pembimbing sampaikan maka tentu 
dosen pembimbing senang sekali, karena itu tanda bagi dosen pembimbing berhasil dalam membimbing mahasiswanya. Selain itu, mempermudah pekerjaan dosen sebagai pembimbing untuk segera mendaftarkan mereka pada sidang tugas akhir jika sudah layak pada semua bab. Jika mahasiswa atau mahasiswi bimbingan lulus dengan nilai memuaskan, memberikan kepuasan batin tersendiri bagi dosen pembimbing yang tidak dapat diukur dengan materi.

Pada hasil wawancara dengan dosen kedua menujukkan hasil bahwa dosen tersebut mengerti apa arti dari internet, www, email, dan news group. Dari beberapa aplikasi internet yang ada, dosen tersebut paling banyak menggunakan email. Dalam melakukan kegiatan bimbingan, dosen tersebut memanfaatkan banyak fasilitas internet yang tersedia, diutamakan yang dapat melakukan face to face walau hanya virtual, karena lebih mempermudah untuk mendapatkan feedback baik dari dosen ataupun mahasiswa.

Strategi bimbingan tugas akhir yang dilakukan oleh dosen tersebut adalah melakukan perbincangan dengan mahasiswa bimbingan mengenai perusahaan yang akan mereka jadikan tempat riset, alasan mereka mengajukan judul tugas akhir, kondisi mereka pada saat itu, kemampuan perihal teori yang akan digunakan hingga pada waktu yang diijinkan pihak perusahaan untuk mengambil riset. Media belajar yang digunakan oleh dosen tersebut adalah buku baik cetak maupun ebook, referensi link jurnal, netbook, notes dan beberapa alat tulis lainnya sebagai penunjang.

Menurut hasil wawancara pada dosen ketiga juga menunjukkan hasil yang baik pada pemahaman dosen tersebut mengenai internet, www, email, dan news group. Aplikasi internet yang banyak digunakan salah satunya adalah email. Yang sering dosen tersebut lakukan saat menggunakan email diantaranya adalah mengirimkan pesan yang sifatnya penting atau formal, mengakses informasi yang masuk melalui kotak pesan pada email, menyimpan informasi, menyebarkan informasi.

Dosen tersebut juga beberapa kali menggunakan elearning untuk melakukan kegiatan bimbingan tugas akhir. Sistem elearning adalah sistem tersebut dapat menunjang kegiatan belajar mengajar yang dilakukan selain dengan metode tatap muka. Sistem elearning merupakan platform yang dapat memfasilitasi pengajar maupun mahasiswa dalam menyampaikan materi kuliah, melakukan komunikasi dua arah dalam penyampaian materi kuliah selain dengan metode tatap muka, pengumpulan tugas, dan sebagainya agar kegiatan belajar-mengajar yang dilakukan secara online dapat dilakukan dengan lebih terukur.

Dalam proses bimbingan, dosen tersebut banyak menggunakan fasilitas whatsapp dan zoom, whatsapp lebih banyak digunakan untuk melakukan perjanjian bimbingan sedangkan zoom digunakan saat proses bimbingan karena dapat melakukan kegiatan secara tatap muka secara virtual. Narasumber persiapkan sebelum membimbing tugas akhir adalah menginformasikan kontrak atau peraturan yang menyangkut bimbingan tugas akhir dan menginformasikan atau membagikan outline penulisan tugas akhir dan memastikan bahwa mahasiswa mengetahui dengan jelas cara penulisan tugas akhir yang baik.

Jika dosen pembimbing dapat berhasil melakukan bimbingan secara virtual dengan baik ketika mahasiswa bimbingan menjadi paham dengan apa yang diajarkan adalah pembimbing merasa senang dan puas bahwa tujuan atau output yang telah ditetapkan sebelumnya berhasil dicapai, yaitu dengan fahamnya mahasiswa atas materi yang diberikan.

Pada hasil wawancara dengan dosen keempat, dosen tersebut sudah mengerti apa itu internet beserta aplikasi yang ada di dalamnya. Email dan www adalah yang paling banyak diakses oleh dosen tersebut. Sedangkan dalam proses bimbingan, dosen tersebut lebih banyak memanfaatkan fasilitas internet seperti whatsapp dan email, hal ini dianggap lebih efisien karena whatsapp lebih personal sehingga dapat melakukan video call kapan saja untuk melakukan bimbingan namun terlebih dahulu mahasiswa dianjurkan mengirimkan tugas akhirnya melalui email sehingga dosen dapat memeriksa dan melakukan revisi.

Berdasarkan hasil wawancara dengan dosen kelima menunjukkan pula bahwa dosen tersebut sudah sangat ngerti tentang internet dan aplikasi didalamnya, termasuk penggunaannya dalam kehidupan sehari-hari seperti email yang paling banyak digunakan. Dan untuk kegiatan bimbingan, dosen tersebut juga memanfaatkan media internet yang ada, seperti whatsapp dan zoom. Dosen tersebut merasa hal tersebut sama efektif dengan tatap muka secara langsung di kampus, sehingga dengan adanya media internet lebih mempermudah dosen dan mahasiswa untuk melakukan kegiatan bimbingan tugas akhir.

Pada hasil wawancara dengan dosen keenam menunjukkan hasil bahwa dosen tersebut juga sudah mampu dengan baik memahami internet berserta fungsi yang ada didalamnya. Seperti dosen yang lain, dosen tersebut juga paling banyak memanfaatkan email dalam kehidupan seharihari. Begitu pula dalam kegiatan bimbingan, penggunaaan aplikasi internet seperti whatsapp dan zoom juga sangat membantu, hal ini dikarenakan banyak menguntungkan baik untuk mahasiswa dan juga dosen pembimbing.

Dari semua narasumber dosen pembimbing tersebut dapat diambil kesimpulan bahwa dosen UBSI sudah terbiasa dengan penggunaan internet dalam kehidupan sehari-hari, hal ini juga disebabkan oleh UBSI selama ini banyak menggunakan media internet untuk kegiatan dosen dan staff sehari-hari, sehingga dosen tidak asing dengan hal tersebut. Setiap dosen yang ada di UBSI memiliki email dari kampus yang sering digunakan untuk melakukan berbagai kegiatan yang ada di kampus. Selain itu, terdapat beberapa aplikasi yang memang dikhususkan untuk internal sehingga dosen sudah terbiasa menggunakan internet sehari-hari dalam melakukan kegiatan kampus, baik itu dilakukan di kampus sendiri dan juga dilakukan di rumah yang dapat diakses sewaktu-waktu.

Fasilitas yang telah disediakan oleh kampus bukan berarti tidak ada kekurangan. Beberapa dosen pembimbing sedikit 
mengeluhkan perihal website elearning kampus yang sering down, namun kampus juga tidak tinggal diam karena kampus juga sedang merencanakan untuk menambahkan bandwith sehingga dosen dan mahasiswa tidak lagi mengeluhkan masalah website yang down saat diakses oleh banyak orang.

Dosen banyak menggunakan fasilitas internet selain untuk kebutuhan bimbingan juga untuk membantu dosen dalam melakukan kegiatan tridarma pendidikan, terutama dalam hal penelitian, sehingga banyak dosen perlu mencari referensi jurnal, skripsi, tesis, disertasi, ebook dan lain-lain yang tersedia di internet. Hal ini dianggap sangat membantu karena mencari literatur di internet lebih mudah dan pilihannya lebih banyak dibandingkan datang ke perpustakaan, dan dapat lebih mudah juga mencari sumber literatur terbaru minimal 10 tahun terakhir.

Selain untuk melakukan kegiatan penelitian, banyak dosen juga memanfaatkan aplikasi internet dalam melakukan kegiatan bimbingan tugas akhir yang mana juga merupakan bagian dari tridarma dosen. Dalam melakukan kegiatan bimbingan, setiap dosen memiliki strategi masing-masing. Mayoritas dosen menekankan pada kemampuan dosen tersebut untuk memahami outline tugas akhir agar dapat disampaikan pada mahasiswa bimbingan pada saat bimbingan perdana.

Media yang digunakan oleh dosen pembimbing ada banyak sekali yang digunakan, namun pada umumnya dosen pasti membuat group chat whatsapp yang terdiri dari dosen pembimbing satu dan dua, dan juga para mahasiswa bimbingan. Untuk melakukan kegiatan bimbingan, diserahkan kepada dosen masing-masing ingin menggunakan media apa. Mayoritas dosen UBSI banyak yang menggunakan media whatsapp dan zoom untuk melakukan kegiatan bimbingan.

Penggunaan whatsapp dilakukan untuk konfirmasi kegiatan yang akan dilakukan, seperti laporan pengiriman tugas akhir melalui email, membuat perjanjian untuk melakukan bimbingan secara tatap muka atau virtual, dan menanyakan kepada mahasiswa perihal kemajuan revisi atau pengerjaan tugas akhir. Sedangkan aplikasi zoom digunakan untuk melakukan bimbingan secara tatap muka secara virtual, hal ini dianggap efisien oleh sebagian besar dosen pembimbing karena dengan melakukan tatap muka melalui zoom, mahasiswa dan dosen pembimbing dapat melakukan interaksi seperti pada saat tatap muka di kampus. Selain itu, mahasiswa dan dosen pembimbing merasa dimudahkan karena tidak perlu melakukan bimbingan secara langsung di kampus.

Kendala lokasi kampus UBSI yang tersebar di beberapa daerah menyulitkan mahasiswa dan dosen untuk melakukan bimbingan secara langsung, terkadang dosen pun merasa iba kepada mahasiswa bimbingan yang tempat tinggalnya jauh dari kampus dimana dosen tersebut berada, maka dari itu UBSI tidak mewajibkan mahasiswa dan dosen untuk melakukan bimbingan secara tatap muka langsung, kampus memberikan kebebasan untuk dosen pembimbing menggunakan fasilitas yang ada untuk mempermudah kegiatan bimbingan agar lebih efisien.

Berdasarkan keterangan dari dosen pembimbing yang menjadi narasumber dalam penelitian ini, mahasiswa mampu menerima masukan dan pengajaran dosen selama bimbingan menggunakan aplikasi internet, sehingga untuk kedepannya proses kegiatan bimbingan tugas akhir yang biasanya dilakukan secara manual dengan tatap muka langsung dapat dialihkan ke digital seperti penggunaan zoom, whatsapp, dan lain-lain. Adanya aplikasi internet ini memberikan efisiensi pada dosen pembimbing dan mahasiswa terutama masalah waktu, karena dapat dilakukan kapan saja di tempat tinggal masing-masing tanpa harus menempuh perjalanan ke kampus yang menghabiskan waktu cukup banyak terutama bagi mahasiswa yang tinggal di daerah jabodetabek.

Dosen pembimbing diharapkan memiliki beragam inovasi sehingga dapat menunjang kegiatan bimbingan tugas akhir, seperti melakukan bimbingan secara virtual, mengajarkan mahasiswa cara mencari referensi jurnal, buku, skripsi, tesis, disertasi, yang dapat menunjang pengerjaan tugas akhir, dan juga mengajarkan cara sitasi yang benar. Banyak mahasiswa mengalami kendala dalam pembuatan tugas akhir, hal ini dikarenakan mereka belum memiliki pengalaman dalam membuat suatu karya dan menyusunnya dalam sebuah laporan dan harus mengaitkannya dengan teori yang ada. Disinilah peran seorang dosen pembimbing diperlukan, untuk memberikan arahan dan bimbingan pada mahasiswa agar mampu mengerjakan tugas akhir sebaik mungkin. UBSI telah memberikan fasilitas yang sangat baik kepada civitas akademik perihal internet terutama kepada dosen. Dosen pembimbing dapat mengakses internet di kampus UBSI cabang manapun dan kapanpun, selain itu kampus juga memberikan subsidi kuota kepada para dosen untuk memudahkan proses kegiatan belajar mengajar, sehingga tidak ada alasan bagi dosen pembimbing untuk menolak bimbingan melalui virtual karena UBSI sudah memberikan fasilitas yang sangat memadai.

Mahasiswa yang sedang mengerjakan tugas akhir juga pada umumnya merasa dimudahkan dalam proses bimbingan jika dosen pembimbing memanfaatkan aplikasi internet yang ada, hal ini dikarenakan beragam faktor, selain karena Jabodetabek yang lalu lintasnya padat juga tidak semua mahasiswa UBSI berasal dari Jabodetabek, sehingga ketika bimbingan secara virtual ini diterapkan, mereka dapat mengakses dimanapun tanpa harus datang ke kampus untuk melakukan bimbingan. Selain mahasiswa, dosen pembimbing pun merasa diuntungkan karena tidak perlu harus pergi ke kampus untuk melakukan proses bimbingan, semua dapat dilakukan secara virtual. Beberapa kali UBSI melakukan rapat, workshop, dan seminar melalui media zoom, sehingga dosen sudah terbiasa dengan aplikasi internet tersebut, sehingga dalam proses bimbingan tugas akhir, dosen pembimbing tidak ada kendala dalam kegiatan bimbingan secara virtual.

Dalam dunia pendidikan manfaat internet ini sangat besar, selain untuk menambah wawasan dan pengetahuan 
mahasiswa khususnya, Dari hasil penelitian yang didapat bahwa mahasiswa secara umum telah menggunakan internet sebagai sarana pendukung dalam penyelesaian tugas kuliahnya. Internet digunakan sebagai sarana transaksi informasi yang didapat dari dosen. Mahasiswa tidak perlu khawatir kekurangan informasi karena dengan memanfaatkan fasilitas internet, mereka dapat mengakses informasi tanpa batas, hal itu dapat mengembangkan kemampuan dan juga pengetahuannya bahkan untuk pelajaran yang tidak ia dapatkan selama perkuliahan. Sehingga internet ini sebagai alat pengembangan kemampuan atau skill mahasiswa itu sendiri

Dengan demikian semakin banyaknya wawasan ilmu yang diperoleh secara tidak langsung membuka cakrawala, menjadikan pribadi lebih unggul dan maju. Internet merupakan teknologi besar yang berkembang digunakan di seluruh dunia dan memiliki manfaat multifungsi. Dapat dilihat bahwa mahasiswa dapat menggunakannya sebagai sarana komunikasi, baik secara interpersonal yang dilakukan antara mahasiswa dengan dosen maupun mahasiswa dengan mahasiswa, maupun cakupannya yang sangat luas seperti komunikasi massa dengan audience yang lebih luas, seperti penggunaan aplikasi teleconference dengan audiens yang tak terbatas, maupun penggunaan aplikasi audio visual guna mengembangkan ilmunya..

Di internet tersedia beragam fasilitas yang dapat digunakan para pengguna, Bahkan banyak menunjukan bahwa pengguna internet yang paling banyak mengunjungi situs www pada sistem search engine mereka seperti penggunaan google. Karena fasilitas tersebut banyak digunakan dalam pencarian informasi yang lebih luas dan lebih mudah, tak hanya itu saja cukup menuliskan kata yang dicari secara otomatis langsung menuju page yang diinginkan

Secara garis besar mahasiswa mengetahui bahwa Internet merupakan suatu jaringan komunikasi yang menghubungkan satu media elektonik dengan media yang lainnya. Standar teknologi pendukung yang dipakai secara global adalah Transmission Control Protocol atau Internet Protocol Suite berisi halaman web, gambar, video, dan konten online lainnya yang dapat diakses melalui browser web .

WWW ini berfungsi sebagai penyedia data dan informasi yang dapat diakses orang lain dari berbagai belahan dunia. Dengan adanya WWW di internet dapat memberikan kemudahan dan kecanggihan para pengguna internet sehingga lebih cepat dan mudah informasi didapat. Dengan WWW memungkinkan pengguna untuk berselancar dengan mudah hanya melalui sebuah alamat URL atau link. Untuk mengakses WWW perlu menggunakan koneksi internet.

Layanan yang didapat dari penggunaan web ini, mahasiswa dapat menggunakannya untuk berbagai jenis kegiatan seperti penggunaan email yahoo, gmail, maupun email personal yang telah dibuat dari kampus UBSI, selain itu mahasiswa juga dapat mengakses website baik itu website kampus, e-learning UBSI maupun website-website pendukung lain seperti website terkait jurnal-jurnal nasional maupun internasional dan juga website dari berbagai institusi maupun dalam penggunaan e-book, sehingga dapat mengakses buku secara mudah dan praktis tanpa kesulitan mencari tahun buku tersebut terbit karena telah tersedia secara lengkap.

Dalam mendukung kegiatan belajar mahasiswa banyak yang menggunakan aplikasi WWW (World Wide Web), email dan new group atau e-learning UBSI. WWW ini digunakan biasanya untuk mencari jurnal atau ebook yang berhubungan dengan pengerjaan Tugas Akhir. Selain itu mahasiswa juga menggunakan fasilitas email sebagai sarana dalam bimbingan tugas akhir, menggunakan fasilitas tersebut untuk mengirimkan hasil revisi tugas akhir serta untuk melakukan interaksi dengan dosen pembimbing, hal itu dinilai efektif karena akan membuat lebih efektif dan efisien, dapat digunakan untuk bimbingan di mana dan kapan saja.

Selain itu kehadiran dari situs penterjemah juga tidak kalah pentingnya digunakan para mahasiswa dalam membantu penulisan mereka. Salah satu situs penterjemah Bahasa asing khususnya Bahasa inggris yaitu penggunaan google translate. Dengan adanya google translate ini memudahkan mahasiswa dalam menterjemahkan kata menjadi Bahasa inggris. Ini dinilai lebih efektif dan efisien karena mereka tak perlu mencari kamus atau membawa kamus jika pergi kemanapun. Selain itu untuk mahasiswa tingkat akhir khususnya penggunaan google translate ini teramat penting terutama dalam pembuatan karya ilmiah sperti penulisan untuk abstrak maupun jika mereka ingin membuat artikel skala internasional.

Situs penyedia jasa elektronik mail atau biasa disebut dengan e-mail, ini juga banyak diakses mahasiswa dalam mendukung kegiatan belajar mengajarnya, dengan adanya fasilitas email seperti yahoo maupun gmail mereka dapat mengirim tugas-tugas terkait perkuliahan dan tidak hanya itu dalam situs tersebut juga terdapat beberapa informasi seputar pengetahuan dan teknologi sehingga tidak hanya digunakan sebagai sarana mengirim pesan namun juga sarana memperoleh informasi yang up to date seputar pemberitaan

Selain itu tanggapan terkait elearning bahwa mereka bependapat bahwa elearning merupakan tempat belajar mengajar dalam jaringan ( online ), sistem elearning ini juga membantu dalam mencari referensi tugas akhir, sistem elarning ini sudah cukup maksimal karena didalamnya sudah tercantum banyak referensi jurnal dan tugas akhir yang ada di sistem e-learning UBSI. Hal ini untuk tambahan dalam penulisan daftar pustaka. Dalam sistem e-learning tersebut juga memudahkan adik-adik kelas dalam mencari sumber bahan bacaan dari kakak-kakak tingkat. Karena dalam elearning terdapat kumpulan tugas akhir kakak senior yang dapat diakses dengan mudah dimana saja dan kapan saja

Dalam proses belajar mengajar juga menggunakan fasilitas pendukung seperti penggunaan whatsapp, email dan juga virtual video seperti zoom, ini membuat mahasiswa merasa senang dan juga diuntungkan karena tidak perlu sering tatap muka dikarenakan terkadang mahasiswa mendapat pembimbing yang berbeda cabang seperti lintas 
jabodetabek, hal ini dapat mempersingkat waktu dan dapat pula dilakukan di rumah.

Pendapat mahasiswa terkait dosen yang membimbingnya dengan menggunakan fasilitas internet dinilai sangat baik, karena dosen mampu menggunakan fasilitas-fasilitas yang ada dalam internet tersebut. Apalagi di jaman pandemic seperti ini, mahasiswa tingkat akhir merasakan kesulitan jika harus keluar rumah, namun dengan adanya fasilitas internet ini memudahkan berinteraksi dengan dosen pembimbing mereka , mereka dapat menggunakan fasilitas aplikasi zoom untuk memudahkan melakukan percakapan ataupun konsultasi dengan dosen pembimbing mereka. Selain itu penggunaan email juga untuk mengoreksi hasil revisi hasil tugas akhir mereka.

Menurut mereka penggunaan internet ini juga sebagai bentuk tuntutan karena saat ini di era perkembangan teknologi komunikasi dan informasi tak jarang tugas mata kuliah yang diberikan dosen menggunakan fasilitas internet. Seperti yang terjadi saat ini bahwa pembuatan tugas tidak hanya dalam bentuk paper namun juga dikembangkan dalam bentuk audio visual seperti pada penggunaan aplikasi Youtube yang terjadi saat ini.

Mahasiswa juga merasa nyaman belajar di ruang mahasiswa yang terdapat pada sistem e-learning UBSI karena merasa fasilitas cukup lengkap dan memudahkan. Sistem pembelajaran e-learning ini adalah sebagai solusi dari pemerintah sebagai sarana belajar yang dapat diakses dimana saja sehingga tidak perlu melakukan tatap muka guna mencegah penyebaran virus disaat pandemic seperti ini. Proses belajar mengajar yang menggunakan media elektronik khususnya internet sebagai sistem pembelajarannya. Elearning ini juga dinilai sebagai suatu jenis perkembangan teknologi informasi dan komunikasi.

Dengan Elearning, para mahasiswa dapat mengakses materi kuliah, kuis, chat, forum dan tugas secara online. Manfaat e-learning salah satunya dirasakan oleh Mahasiswa itu sendiri, beberapa mata kuliah sudah menggunakan elearning dalam proses pembelajaran.

Elearning juga memudahkan, karena dapat memilih waktu kapan saja dimana saja untuk mengakses perkuliahan tanpa ada batasan tertentu, dan materi juga dapat diakses berulang kali. Mahasiswa dapat mendownload materi dan menyimpannya pada laptop mereka. Sehingga suatu saat mereka ingin belajar, mereka dapat mencarinya dengan mudah karena tersave di halaman document mereka. elearning dapat memberikan kesempatan bagi mahasiswa untuk lebih effort, sehingga timbul usaha nyata untuk menentukan keberhasilan, E-learning ini juga dinilai dapat menghemat biaya khususnya mahasiswa tanpa perlu datang ke kampus sehingga tanpa uang transportasi.

Elearning ini juga sebagai tempat diskusi. Dalam elearning terdapat bagian forum dimana itu sebagai wadah bagi mahasiswa untuk bertanya pada dosen jika ada pelajaran yang tidak di mengerti, melalui forum juga dosen biasanya mengajukan beberapa pertanyaan yang kemudian dijawab secara langsung pada bagan tersebut. Sehingga menciptakan kondisi belajar yang lebih hidup seperti layaknya belajar di kelas secara tatap muka.

Pendapat mahasiswa terkait situs belajar online, elearning UBSI ini masih dinilai belum efektif kenapa karena terkadang mereka mengalami kendala server hal ini mungkin karena sangat penuhnya mahasiswa lain yang akses situs tersebut, maka terkadang mereka juga mengalami kesulitan login, misalnya pada jam-jam sibuk tertentu seperti pagi dan siang, namun jika diakses malam hari dinilai jauh lebih mudah karena tidak sepenuh jam-jam pagi atau siang.

Dengan menggunakan internet dapat mengakses beberapa karya ilmiah, hasil dari penelitian para mahasiswa dari seluruh Indonesia maupun seluruh dunia. Salah satunya yaitu dengan penggunaan google scholar, di mana ini merupakan fasilitas yang diberikan google kepada para pengguna khususnya para akademisi, para mahasiswa pun banyak menggunakan ini sebagai fasilitas mereka mengakses beberapa karya ilmiah tulisan sebagai bahan penulisan mereka. Selain itu juga dapat mengakses buku-buku online pilihan seperti OAPEN Library. Selain itu juga penggunaan google Archieve untuk dokumen secara bebas dan gratis.

Seperti yang diketahui bahwa dalam penyelesaian tugas akhir perlu beberapa buku-buku referensi, dengan adanya internet memudahkan para mahasiswa dalam mencari teoriteori pendukung yang menunjang penelitian. Berbagai kemudahan telah ditawarkan dari penggunaan internet ini. Sehingga mahasiswa merasa lebih terbantu dan tenang, mereka tidak perlu sibuk mencari buku berwujud, karena sekarang semua serba digital dan tidak perlu berkunjung ke perpustakaan karena kampus juga memiliki akses online perpustakaan UBSI hanya dengan memasukkan nomor induk mahasiswa dan juga password mereka seperti berada dalam ruang perpustakaan namun dalam genggaman gadget mereka.

Penggunaan internet ini jangkauannya lebih luas dari buku. Mahasiswa dapat mengakses pelajaran tidak hanya pada tingkatnya saja namun lebih dari itu dapat digunakan lintas prodi misalnya seperti jurusan ilmu komunikasi namun bisa mengakses pelajaran ekonomi. Hal tersebut dapat memperluas jangkauan kemampuan mahasiswa.

Kehadiran internet juga membantu mahasiswa dalam mengerjakan tugas. Karena internet menyediakan berbagai informasi yang berkaitan dengan tugas-tugas mereka. Namun jika dibiarkan terkadang mahasiswa juga ada yang menyalahgunakannya seperti tidak adanya bentuk upaya membuatnya sendiri dan terkadang tak jarang copy paste dalam pengerjaannya. Hal ini nampak jelas pada pembuatan tugas-tugas makalah misalnya. Sebagian mahasiswa mirip tulisannya seperti yang dimiliki orang lain

Dari segi waktu memang internet ini dinilai lebih cepat. Bayangkan saja jika mahasiswa tidak menggunakan internet mereka membutuhkan waktu dalam mencari sumber, seperti harus mengunjungi perpustakaan atau mencarinya di toko buku, yang terkadang belum tentu ada apa yang dicarinya. Dengan menggunakan internet hitungannya hanya per menit 
atau per detik apa yang dicari nampak langsung pada layar laptop maupun gadget mereka.

Seperti yang kita ketahui sebelum adanya media internet, manusia dalam mencari informasi cukup banyak serta membutuhkan biaya dan waktu yang cukup lama, seperti ketika penemuan dan pencarian informasi yang harus menggunakan media kertas seperti misalnya buku, koran maupun majalah dan bahkan mencarinya sebuah katalog maupun media lain.

Mencari dan penggunaan informasi merupakan kegiatan yang tak terpisahkan dalam kehidupan sehari-hari. Mencari dan menggunakan informasi adalah bagian tetap dan akan terus berlangsung selama hidup, begitupun mahasiswa mencari informasi tanpa membuang banyak waktu. Banyak mahasiswa menggunakan ini sebagau Langkah yang akurat, relevan, efektif dan juga ekonomis.

Internet sebagai alternatif pencarian informasi bagi mahasiswa selain melalui perpustakaan. Internet menjadi pilihan sumber informasi yang mempunyai banyak manfaat jika dibanding dengan sumber informasi lain.

Saat ini sudah semakin banyak instansi maupun lembaga pemerintah memiliki koneksi kedalam jaringan internet. Beberapa diantaranya bahkan telah menampilkan lembaganya kedalam bentuk situs homepage pada world wide web (www). Perkembangan internet di Indonesia juga menunjukkan perkembangan yang cukup pesat

Setelah diteliti ternyata banyak alasan mengapa para mahasiswa menggunakan internet. Hal tersebut dikarenakan sebagai tuntutan seperti yang terjadi pada era saat ini yang semua serba digital (digitalisasi), selanjutnya ini dinilai efektif dan dianggap jauh lebih lengkap informasi yang tersedia, tidak membuang waktu mereka karena mereka lebih memilih sesuatu yang serba praktis seperti layaknya para kaum milenial, selain itu dorongan untuk menikmati fasilitas gratis yang diberikan kampus karena adanya hotspot wifi di setiap sudut kampus tanpa batas dan bisa diakses selama berada di wilayah kampus serta menginginkan sesuatu yang baru atau up to date dalam mencari informasi yang berkaitan dengan ilmu pengetahuan.

Hal ini sebagaimana yang diungkapkan dalam penelitian Brown (2000) bahwa dalam mengerjakan tugas tertentu dalam mendapatkan informasi tidak bisa dari dirinya sendiri maka mereka akan berusaha untuk mencari sumber informasi secara interpersonal melakukan bertanya baik itu dengan teman, orang lain atau ahli bidang tertentu. Biasanya memilih sumber informasi yang paling mudah, cepat dan murah dalam proses aksesnya Terkait hal itu maka mahasiswa menggunakan tool dalam pencarian informasi mereka

Dengan adanya internet terciptanya komunikasi interaktif , terjadi pertukaran informasi antara pengguna satu dengan lainnya. Tanpa dibatasi oleh ruang dan waktu. Selain itu ini dinilai sebagai bentuk menghemat biaya komunikasi yang dikeluarkan. Bermunculannya berbagai aplikasi di internet seperti e-mail, video, conferencing membantu kemudahan dalam mengaksesnya.
Selain itu memungkinkan interaksi dengan para pakar, dalam hal ini mahasiswa dapat melakukan interaksi pada orang yang dianggap mengetahui atau ahli bidang tertentu dan mereka tidak segan untuk menjawab segala bentuk pertanyaan yang dilontarkan oleh para mahasiswa.

Terkadang internet ini dinilai seperti akses pada koleksi perputakaan tidak terbatas lagi pada koleksi buku dan jurnal dan ini menjadi pusat penyebaran informasi maupun pangkalan data penelitian yang biasanya dikembangkan olah universitas.

Sebagian besar mahasiswa UBSI juga menyatakan jika penggunaan internet intensitasnya sangat tinggi, bahkan hampir setiap hari mereka menggunakan internet tidak hanya untuk sekedar browsing mencari informasi-informasi namun juga Kemudahan mahasiswa dalam mengakses internet tidak dipungkiri membuat banjir akan informasi. Namun terkadang karena kemudahan akses ini juga menambah kekhawatiran karena banyaknya informasi yang beredar terkadang dari sumber yang tidak terpercaya dan bahkan perlu digarisbawahi akan kebenarannya.

Maka dari itu seharusnya mahasiswa lebih cermat dan selektif lagi terhadap informasi yang beredar di internet dan tidak ada salahnya untuk menggunakan buku sebagai acuan utama dalam penyelesaian tugasnya. Sehingga didapatkan informasi yang tepat, akurat serta terjamin akan kebenarannya

Mahasiswa secara umum sangat menyukai penggunaan internet, dan menyatakan bahwa internet ini sangatlah bermanfaat, karena dinilai sangat mudah dalam mengakses pencarian informasi dan sungguh tak terbatas, Selain itu faktor efisiensi waktu dikarenakan banyak tugas mereka yang tidak hanya satu mata kuliah namun juga beberapa mata kuliah dengan jadwal deadline yang mengharuskan mereka harus segera menyelesaikan tugasnya.

Tak hanya itu saja, internet juga membantu mahasiswa tingkat akhir dalam mencari referensi sumber-sumber yang mendukung penelitian Namun penggunaan internet juga memperhatikan faktor kuota, kendalanya yaitu di kuota karena ada beberapa situs yang memerlukan banyak kuota lebih seperti pada penggunaan aplikasi video conference seperti aplikasi zoom, selain itu juga dipengaruhi oleh sinyal yang terkadang tidak stabil.

\section{KESIMPULAN}

Berdasarkan hasil wawancara kepada 12 narasumber yang terdiri dari 6 dosen pembimbing dan 6 mahasiswa akademi komunikasi yang sedang mengerjakan tugas akhir, maka dapat diambil kesimpulan bahwa dosen dan mahasiswa UBSI sudah mengerti penggunaan internet dan aplikasi yang ada di dalamnya termasuk menggunakannya dalam kehidupan sehari-hari salah satunya dalam melakukan proses bimbingan tugas akhir. News group yang digunakan UBSI adalah elearning juga sering digunakan oleh dosen dan mahasiswa namun lebih ke kegiatan belajar mengajar, tidak untuk bimbingan tugas akhir. 
Email dan www merupakan aplikasi internet yang banyak dipakai oleh dosen dan mahasiswa dalam kegiatan seharihari, sedangkan dalam kegiatan bimbingan, dosen pembimbing dan mahasiswa banyak menggunakan aplikasi whatsapp dan zoom. Pada umumnya dosen pembimbing akan membuat forum diskusi berupa whatsapp kepada mahasiswa bimbingan sehingga mempermudah mahasiswa dan dosen dalam melakukan komunikasi, termasuk dalam hal konfirmasi pengiriman email tugas akhir ke dosen pembimbing dan melakukan perjanjian bimbingan tatap muka virtual melalui aplikasi zoom.

Seperti yang diketahui bahwa dalam penyelesaian tugas akhir perlu beberapa buku-buku referensi, dengan adanya internet memudahkan para mahasiswa dalam mencari teoriteori pendukung yang menunjang penelitian. Berbagai kemudahan telah ditawarkan dari penggunaan internet ini. Sehingga mahasiswa merasa lebih terbantu dan tenang, mereka tidak perlu sibuk mencari buku berwujud, karena sekarang semua serba digital dan tidak perlu berkunjung ke perpustakaan karena kampus juga memiliki akses online perpustakaan UBSI hanya dengan memasukkan nomor induk mahasiswa dan juga password mereka seperti berada dalam ruang perpustakaan namun dalam genggaman gadget mereka.

Mahasiswa secara umum sangat menyukai penggunaan internet, dan menyatakan bahwa internet ini sangatlah bermanfaat, karena dinilai sangat mudah dalam mengakses pencarian informasi dan sungguh tak terbatas, Selain itu faktor efisiensi waktu dikarenakan banyak tugas mereka yang tidak hanya satu mata kuliah namun juga beberapa mata kuliah dengan jadwal deadline yang mengharuskan mereka harus segera menyelesaikan tugasnya.

Tak hanya itu saja, internet juga membantu mahasiswa tingkat akhir dalam mencari referensi sumber-sumber yang mendukung penelitian Namun penggunaan internet juga memperhatikan faktor kuota, kendalanya yaitu di kuota karena ada beberapa situs yang memerlukan banyak kuota lebih seperti pada penggunaan aplikasi video conference seperti aplikasi zoom, selain itu juga dipengaruhi oleh sinyal yang terkadang tidak stabil.

Dengan adanya internet ini sangat membantu dosen pembimbing dan mahasiswa dalam melakukan kegiatan bimbingan tanpa harus bertemu langsung, hal ini dikarenakan kampus UBSI yang tersebar di beberapa daerah dan kemacetan Jabodetabek yang mendasari para dosen pembimbing berinisiatif untuk memanfaatkan media digital untuk melakukan kegiatan bimbingan. Dengan kegiatan bimbingan secara virtual tersebut ternyata memberikan hasil yang positif, yaitu mahasiswa dapat memahami dan menangkap apa yang dosen pembimbing sampaikan sama seperti melakukan bimbingan tatap muka di kampus, hal ini menunjukkan bahwa pada era digital saat ini juga berpengaruh besar pada kegiatan bimbingan tugas akhir antara dosen dan mahasiswa.
Fasilitas yang telah disediakan oleh kampus bukan berarti tidak ada kekurangan. Beberapa dosen pembimbing sedikit mengeluhkan perihal website elearning kampus yang sering down, namun kampus juga tidak tinggal diam karena kampus juga sedang merencanakan untuk menambahkan bandwith sehingga dosen dan mahasiswa tidak lagi mengeluhkan masalah website yang down saat diakses oleh banyak orang.

Melihat dari bermanfaatnya media digital yang ada saat ini dalam kegiatan bimbingan tugas akhir, diharapkan elearning UBSI tidak hanya dimanfaatkan untuk kegiatan belajar mengajar namun juga untuk kegiatan bimbingan tugas akhir atau skripsi. Selain itu, dilihat dari efektifnya kegiatan bimbingan menggunakan berbagai aplikasi internet maka dapat menjadi pertimbangan kampus untuk mengaplikasikannya juga dalam kegiatan belajar mengajar sehari-hari sehingga tidak perlu adanya kegiatan belajar mengajar di kampus untuk meminimalkan biaya dan memudahkan mahasiswa untuk melakukan kegiatan belajar mengajar dimanapun mereka berada. UBSI sudah menggunakan sistem berbasis teknologi komputer selama ini sehingga bukan hal yang sulit bagi para civitas UBSI untuk mewujudkan perkuliahan secara digital.

Selain itu, diharapkan UBSI juga memberikan workshop mengenai aplikasi internet kepada dosen dan juga mahasiswa. Hal ini disebabkan UBSI telah banyak menggunakan aplikasi internet dalam kegiatan perkuliahan, sehingga perlu adanya pelatihan untuk dosen dan mahasiswa perihal penggunaan aplikasi internet yang telah diterapkan oleh UBSI selama ini. Diperlukan effort yang cukup tinggi bagi UBSI untuk melatih semua dosen agar benar-benar mampu menguasai aplikasi internet, hal ini disebabkan oleh ada beberapa dosen yang masih belum terbiasa dengan digitalisasi, sedangkan kebutuhan penggunaan internet ini sangat dibutuhkan untuk kemajuan pendidikan, sehingga mau tidak mau para pendidik dituntut untuk mampu menguasai aplikasi internet. Begitu pula untuk mahasiswa, UBSI perlu melakukan pelatihan terutama kepada mahasiswa baru agar mampu memahami aplikasi internet apa saja yang diterapkan oleh UBSI, agar mahasiswa tidak mengalami kesulitan dalam melakukan kegiatan belajar mengajar, terutama dalam hal bimbingan tugas akhir.

Perubahan dunia digital sangat cepat, dalam hal pembuatan tugas akhir pun mengalami beberapa perubahanperubahan mengikuti perkembangan yang ada, seperti dalam hal sitasi yang dahulunya dilakukan secara manual, saat ini sudah menggunakan aplikasi internet. Sehingga dosen pembimbing dan mahasiswa dituntut untuk mampu mengikuti perkembangan yang ada. Dalam hal ini, dosen pembimbing diharapkan memiliki kemampuan lebih dalam hal aplikasi internet sehingga dapat memberikan arahan kepada mahasiswa bimbingan agar dapat menunjang dalam pembuatan tugas akhir. Peran dari dosen pembimbing sangat tinggi dalam kegiatan bimbingan tugas akhir agar mahasiswa mampu menciptakan karya tugas akhir dengan baik. 
Terimakasih kami ucapkan kepada DIKTI yang telah memberikan dana hibah Penelitian Dosen Pemula sehingga tercipta penelitian ini. Terimakasih kepada Universitas Bina Sarana Informatika yang telah memberikan fasilitas kepada kami selaku dosen untuk dapat melakukan hibah Penelitian Dosen Pemula ini.

\section{DAFTAR PUSTAKA}

[1] D. Mulyana, lmu Komunikasi: Suatu Pengantar. Bandung: Remaja Rosdakarya, 2015.

[2] E. A. Sosiawan, "Kajian Teoritis Komunikasi Virtual ( Internet dalam Prespektif Ilmu Komunikasi)," 2008. [Online]. Available: http://edwi.dosen.upnyk.ac.id/Kajian internet kom.pdf .

[3] L. J. Moleong, Metodologi Penelitian Kualitatif. Bandung: Remaja Rosdakarya, 2017.

[4] Sugiyono, Metode Penelitian Kuantitatif Kualitatif dan $R \& D$. Bandung: Alfabeta, 2018.

[5] B. Bungin, Metodologi Penelitian Kualitatif, Aktualisasi Metodologis Ke Arah Ragam Varian Kontemporer. Jakarta: Raja Grafindo Persada, 2017. 